\title{
Overexpression of TGF- $\beta$ by infiltrated granulocytes correlates with the expression of collagen mRNA in pancreatic cancer
}

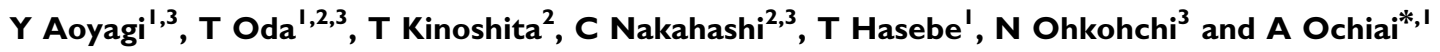 \\ 'Pathology Division, National Cancer Center Research Institute East, Kashiwanoha 6-5-I, Kashiwa, Chiba 277-8577, Japan; ${ }^{2}$ Hepato-Biliary-Pancreatic \\ Surgery Division, National Cancer Center Hospital East, Kashiwanoha 6-5-1, Kashiwa, Chiba 277-8577, Japan; ${ }^{3}$ Department of Surgery, Institute of \\ Clinical Medicine, University of Tsukuba, Tennodai I-I-I, Tsukuba, Ibaraki 305-8575, Japan
}

Pancreatic cancer is often associated with an intense production of interstitial collagens, known as the desmoplastic reaction. To understand more about desmoplasia in pancreatic cancer, the expression of mRNA for type I and III collagens and potent desmoplastic inducing growth factors transforming growth factor- $\beta$ (TGF- $\beta$ ), connective tissue growth factor (CTGF), acidic and basic fibroblast growth factor (FGF), platelet-derived growth factor (PDGF) A and C and epidermal growth factor (EGF) was analysed by quantitative RT-PCR. Expression of both collagens in 23 frozen primary pancreatic cancer nodules was significantly higher than that in 15 nonneoplastic pancreatic tissues. The expressions of mRNAs for TGF- $\beta$, acidic FGF, basic FGF and PDGF C were likewise higher in surgical cancer nodules, while that of CTGF, PDGF A and EGF were not. Among these growth factors, the expression of TGF- $\beta$ mRNA showed the most significant correlation with that of collagens $(P<0.000 \mathrm{I})$. By immunohistochemistry, TGF- $\beta$ showed faint cytoplasmic staining in cancer cells. In contrast, isolated cells, mainly located on the invasive front surrounding cancerous nests, were prominently and strongly stained. These TGF- $\beta$-positive cells contained a segmented nucleus, were negative for anti-macrophage (CD68) and positive for anti-granulocyte antibodies, indicating their granulocytic nature. In conclusion, TGF- $\beta$ seemed to play a major role among the various growth factors in characteristic overproduction of collagens in pancreatic cancer. Moreover, the predominant cells that express TGF- $\beta$ were likely to be infiltrated granulocytes (mostly are neutrophils) and not pancreatic cancer cells.

British Journal of Cancer (2004) 9 I, 1316- |326. doi: I0.1038/sj.bjc.6602 I4 I www.bjcancer.com

Published online 7 September 2004

(c) 2004 Cancer Research UK

Keywords: pancreatic cancer; desmoplastic reaction; TGF- $\beta$; granulocytes; quantitative RT-PCR

Pancreatic adenocarcinoma is a highly lethal disease with no definitive therapy (Warshaw and Fernandez-del Castillo, 1992; Neoptolemos et al, 2003). One hallmark of pancreatic adenocarcinoma is the intense production of interstitial components, known as the desmoplastic reaction (Iacobuzio-Donahue et al, 2002). As a result, the proportion of pancreatic cancer cells is less than $20-$ $40 \%$ of the tumour mass (Kloppel et al, 1985), while the remaining $60-80 \%$ includes interstitial cells (fibroblast, endocells and inflammatory cells) and proliferated interstitial components include collagens, followed by fibronectin, laminin and proteoglycan (Gress et al, 1995; Imamura et al, 1995; Linder et al, 2001).

The desmoplastic reaction has been reported to be stimulated by various growth factors including epidermal growth factor (EGF) (Gospodarowicz, 1983), platelet-derived growth factor (PDGF) (Gospodarowicz, 1983; Tahara, 1990), connective tissue growth factor (CTGF) (Frazier et al, 1996), fibroblast growth factor (FGF) (Gospodarowicz, 1983; Powers et al, 2000) and transforming growth factor- $\beta$ (TGF- $\beta$ ) (Roberts et al, 1986; Fine and Goldstein, 1987; Sappino et al, 1990; McCartney-Francis and Wahl, 1994). In various malignancies including pancreatic cancer, overexpression

*Correspondence: Dr A Ochiai; E-mail: aochiai@east.ncc.go.jp Received 12 March 2004; revised I 4 July 2004; accepted 16 July 2004; published online 7 September 2004 of these growth factors is frequently observed (Korc et al, 1992; Friess et al, 1993; Yamanaka et al, 1993; Ebert et al, 1995; Gold, 1999; Wenger et al, 1999) and has been associated with a significant decrease in the survival and advanced tumour stage (Friess et al, 1993). Comprehensive analysis, however, concerning the growth factors that have the strongest impact on the induction of the desmoplastic reaction has never been reported; furthermore, as to which one of the cellular component (i.e. neoplastic cells and interstitial cells) contributing to the overexpression of growth factors inducing desmoplasia in pancreatic cancer has remained obscure. It is generally believed that the cancerous component secretes the growth factors that give rise to this host reaction (Korc et al, 1992; Friess et al, 1993; Yamanaka et al, 1993; Ebert et al, 1995; Gold, 1999; Wenger et al, 1999). However, as haematopoietic cells including lymphocytes, macrophages and granulocytes are also capable of secreting growth factors (Roberts and Sporn, 1988; Grotendorst et al, 1989; Leonardi et al, 2000), we hypothesised that infiltrated haematopoietic cells in addition to cancer cell itself could be a source of growth factors that result in induction of desmoplasia.

In order to better understand the molecular mechanism of behind desmoplasia in pancreatic cancer, we have analysed the expression of mRNA of collagens and potent desmoplastic inducing growth factors. We demonstrate that expression of collagens was significantly correlated with that of TGF- $\beta$ in primary pancreatic cancers, and, moreover, that the main source 
of TGF- $\beta$ is likely to be infiltrated granulocytes (mostly are neutrophils) and not cancer cells.

\section{MATERIAL AND METHODS}

\section{Surgical resected tissues of human pancreatic cancer}

The pancreatic cancer tissues used in this study were obtained from patients (10 male; 13 female) undergoing surgery for pancreatic adenocarcinoma in the National Cancer Center Hospital East Japan from 1999 to 2002. The median age was 66 years, ranging from 52 to 81 . There was one patient with stage I, two patients with stage II, 10 patients with stage III and 10 patients with stage IV disease. In all, 15 non-neoplastic pancreatic tissues obtained from the same patients were also evaluated. Specimens ranging from 100 to $300 \mathrm{mg}$ were immediately homogenised in TRIZOL reagent solution (Life Technologies, Gaithersburg, MD, USA) using multi-beads shocker (YASUI kikai, Osaka, Japan) after surgical removal. Samples were stored at $-80^{\circ} \mathrm{C}$ until RNA was extracted.

\section{Cultured cell lines}

Six human pancreatic cancer cell lines were analysed. ASPC-1, BxPC-3, CAPAN-1 and MiaPaca-2 were obtained from the American Type Culture Collection (ATCC) (Bethesda, MD, USA), PSN-1 was from the Central Animal Laboratory National Cancer Center Research Institute (Tokyo, Japan) and SUIT-2 cells were generously provided by Dr Iwamura (Miyazaki Medical College, Miyazaki, Japan). Two gastric cancer cell lines (KATO3 and MKN45), two colon cancer cell lines (COLO201 and SW1116) and two fibroblast (MRC-5 and WI-38) cell lines were also analysed (ATCC). All cell lines were grown in either RPMI1640 or Dulbecco's modified Eagle medium (Sigma Aldrich, Taufkirchen, Germany) containing 10\% heat-inactivated foetal bovine serum (Sigma). All cell lines were kept in a humidified atmosphere containing $5 \% \mathrm{CO}_{2}$ at $37^{\circ} \mathrm{C}$. Approximately $1 \times 10^{7}$ cells were sheared in $1 \mathrm{ml}$ of TRIZOL reagent solution using a $21 \mathrm{G}$ needle. The homogenate was kept at $-80^{\circ} \mathrm{C}$ until RNA was extracted.

\section{RNA extraction}

RNA from surgically resected tissues was extracted from about $100 \mathrm{mg}$ of homogenised tissue in TRIZOL reagent solution. Samples were treated with $40 \mathrm{U}$ of RNase-free DNase I (TAKARA, Shiga, Japan) in $200 \mu \mathrm{l}$ DEPC (diethylpyrocarbonate)-treated water, $10 \mathrm{mM} \mathrm{MgCl}_{2}$ and $40 \mathrm{U}$ of RNase Inhibitor (TOYOBO, Osaka, Japan) at room temperature for $15 \mathrm{~min}$.

\section{Reverse transcription (RT)}

All cDNAs were synthesised from $10 \mu \mathrm{g}$ total RNA using $50 \mu \mathrm{m}$ oligo $(\mathrm{dT})_{20}$ primer in a total volume of $50 \mu$ l using ThermoScript ${ }^{\mathrm{TM}}$
RT-PCR System (Life Technologies) according to the manufacturer's protocol. cDNAs were purified using the QIA quick PCR purification Kit (QIAGEN, Hilden, Germany) and eluted in $100 \mu \mathrm{l}$ of $10 \mathrm{~mm}$ Tris $-\mathrm{HCl}(\mathrm{pH} 8.5)$.

\section{Real-time quantitative $\mathrm{RT}$ - polymerase chain reaction (RT - PCR)}

Expression of type I collagen and type III collagen mRNAs was analysed since they are major proteins of the stromal component. Transforming growth factor- $\beta$, CTGF, acidic FGF (aFGF), basic FGF (bFGF), PDGF A, PDGF C and EGF were analysed as they are potent desmoplastic inducing molecules. Polymerase chain reaction primer pairs for mRNA quantification, intending to flank at least one intron, were designed based on coding sequences obtained from the GenBank Sequence Database (http:// www.ncbi.nlm.nih.gov/Genbank/index.html) (Table 1).

\section{Quantitative real-time RT - PCR}

Quantitative real-time PCR was carried out using a LightCycler ${ }^{\mathrm{TM}}$ instrument (Roche, Mannheim, Germany) using SYBR green. In all, $1 \mu \mathrm{l}$ of cDNA solution corresponding to $100 \mathrm{ng}$ of total RNA was subjected to 40 PCR cycles of $10 \mathrm{~s}$ at $95^{\circ} \mathrm{C}, 10 \mathrm{~s}$ at $53-65^{\circ} \mathrm{C}$ and $5-15 \mathrm{~s}$ at $72^{\circ} \mathrm{C}$ in a $10 \mu \mathrm{l}$ mixture containing $1 \mu \mathrm{l}$ LightCycler-DNA Master SYBR Green I (Roche), $2.25-5 \mathrm{mM} \mathrm{MgCl}_{2}$ and $0.25 \mu \mathrm{M}$ each of forward and reverse gene-specific primers. Polymerase chain reaction conditions and detection temperature of fluorescent products were optimised for each gene by meticulous pilot studies (Table 2). Amplification specificities of the PCR products were confirmed by melting curve analysis of the LightCycler instruments, and re-confirmed by agarose gel electrophoresis.

An external standard curve for each gene was generated using serial $10^{2}$-fold dilutions of RT-PCR products, corresponding to $1 \times 10^{8}-1 \times 10^{2}$ copies $\mu 1^{-1}$, to estimate the gene-specific mRNA copy number per $100 \mathrm{ng}$ total RNA of each sample.

\section{Immunohistochemistry}

The expression of TGF- $\beta$ was investigated by immunohistochemistry (IHC) using anti-human TGF- $\beta 1$ antibody in 23 pancreatic cancer tissues. Potent TGF- $\beta$-producing haematopoietic cells, that is, macrophages or granulocytes, were also visualised by IHC. Paraffin-embedded, formalin-fixed sections were subjected to antigen retrieval by immersion in $0.1 \mathrm{M}$ citrate buffer $(\mathrm{pH} 6.0)$ and microwaving at $95^{\circ} \mathrm{C}$ or by incubation with protease $\mathrm{K}$ (DAKO, Glostrup, Denmark) at room temperature for $10 \mathrm{~min}$. Endogenous peroxidase was inactivated by incubating in $0.3 \%$ $\mathrm{H}_{2} \mathrm{O}_{2}$ in methanol for $10-20 \mathrm{~min}$. Nonspecific binding was blocked by treatment with $5 \%$ skim milk and $2 \%$ bovine serum albumin in PBS for $30 \mathrm{~min}$. Tissues were then incubated with polyclonal rabbit antibodies against anti-human TGF- $\beta 1$ (Santa Cruz Biotechnology, Inc., Santa Cruz, CA, USA), as well as

Table I PCR primers for collagens and potent desmoplastic inducing growth factors

\begin{tabular}{|c|c|c|c|c|c|}
\hline Gene & Accession no. & Position & $\begin{array}{c}\text { Product } \\
\text { length (bp) }\end{array}$ & Forward primer sequence & Reverse primer sequence \\
\hline Type I collagen & NM_000088 & $4010-4390$ & 381 & 5'-CAG TTC GAG TAT GGC GGC G-3' & $5^{\prime}$-GAC AGG GCC AAC GTC GAA G-3' \\
\hline Type III collagen & NM_000090 & $3632-3936$ & 305 & 5'-AAA AAG CTG GCG GTT TTG CC-3' & $5^{\prime}$-CCG TGG AAC ATT CAA AGG AT-3' \\
\hline TGF- $\beta$ & $\times 02812$ & $402-651$ & 250 & $5^{\prime}-\mathrm{CTT}$ CAA CAC ATC AGA GCT CCG A-3' & $5^{\prime}$-GCC CTC AAT TTC CCC TCC AC-3' \\
\hline CTGF & M92934 & $503-87 \mid$ & 369 & 5'-AGC CCA AGG ACC AAA CCG TG-3' & 5'-GGC CGT CGG TAC ATA CTC CA-3' \\
\hline aFGF & $\times 65778$ & $318-468$ & 150 & 5'-GAA CCA TTA CAA CAC CTA TAT-3' & $5^{\prime}$-TTA ATC AGA AGA GAC TGG C-3' \\
\hline bFGF & M27968 & $254-445$ & 192 & 5'-TGA AGG AAG ATG GAA GAT TA-3' & 5'-GAA AAA GTA TAG CTT TCT GC - $3^{\prime}$ \\
\hline PDGF A & A09204 & $266-538$ & 273 & 5'-AGG AAG CTG TCC CCG CTG TC-3' & $5^{\prime}-\mathrm{CGC}$ AGG CGC ACT CCA AAT GC-3' \\
\hline PDGF C & AF260738 & $493-739$ & 247 & 5'-CCA CAA TTC ACA GAA GCT GT-3' & 5'-ATC TTA ССТ ССТ CTG TTA GAA GG-3' \\
\hline EGF & NM_001963 & $3246-3586$ & 341 & $5^{\prime}$-GCC TGC TGA CAC TGA GGA T-3' & $5^{\prime}$-CCC TाT GTT GCC ATA ATG GG-3' \\
\hline
\end{tabular}


Table 2 PCR conditions

\begin{tabular}{llccc}
\hline Gene & $\begin{array}{c}\mathbf{M g C l}_{\mathbf{2}} \\
(\mathbf{m m})\end{array}$ & $\begin{array}{c}\text { Annealing } \\
\text { temp. }\left({ }^{\circ} \mathbf{C}\right)\end{array}$ & $\begin{array}{c}\text { Elongation } \\
\text { time (s) }\end{array}$ & $\begin{array}{c}\text { Detect } \\
\text { temp. }\left({ }^{\circ} \mathbf{C}\right)^{\mathbf{a}}\end{array}$ \\
\hline Type I collagen & 2.25 & 63 & 15 & 88 \\
Type III collagen & 4 & 63 & 10 & 80 \\
TGF- $\beta$ & 3 & 65 & 8 & 86 \\
CTGF & 2.25 & 66 & 13 & 85 \\
aFGF & 4 & 53 & 5 & 81 \\
bFGF & 5 & 58 & 7 & 72 \\
PDGF A & 3 & 68 & 10 & 88 \\
PDGF C & 3 & 56 & 9 & 79 \\
EGF & 4 & 65 & 13 & 72 \\
\hline
\end{tabular}

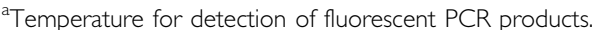

anti-human CD68 mouse monoclonal antibodies (DAKO) and anti-human granulocyte (Medical \& Biological Laboratories Co., Nagoya, Japan) at a dilution of $1: 100$ in a humidified chamber at $4^{\circ} \mathrm{C}$ overnight. Primary antibody reactions of TGF- $\beta$ and granulocyte were enhanced using the Envision + kit (DAKO). CD68 antibody treatment was followed by incubation with rabbit anti-mouse secondary antibody and enhanced using Strept AB Complex/HRP kit (DAKO). The immunoreaction was visualised with $0.05 \% 3,3^{\prime}$-diaminobenzidine (DAB) solution for 1 - $10 \mathrm{~min}$ at room temperature. After washing in distilled water, the specimens were counterstained with haematoxylin, dehydrated and mounted.

As negative control for TGF- $\beta 1$ analysis, the primary antibody was substituted for by anti-green fluorescence protein (GFP) rabbit polyclonal antibodies (Molecular Probes, Inc., Eugene, OR, USA) and processed as described above. As a negative control for granulocyte and macrophage visualisation, anti-mouse $\mathrm{H} 2 \mathrm{~Kb}$ mouse monoclonal antibodies (PharMingen, San Diego, CA, USA) were used.

\section{Double immunofluorescence stain}

In order to corroborate the precise localisation of TGF- $\beta$, five representative pancreatic cancer tissues were subjected to double immunofluorescence staining. Sections were incubated with the primary antibody pairs against (TGF- $\beta+$ CD68) or (TGF$\beta+$ granulocyte) for $1 \mathrm{~h}$ at room temperature in a humidified chamber. Transforming growth factor- $\beta$ was labelled red with Alexa Fluor $546 \mathrm{~F}\left(\mathrm{ab}^{\prime}\right)_{2}$ fragments of goat anti-rabbit IgG (Molecular Probes, Inc., OR, USA) at a dilution of $1: 1000$, and CD68 and granulocytes were labelled green with fluorescein (FITC) horse anti-mouse IgG (Vector Laboratories, Inc., CA, USA) at a dilution of $1: 100$ by incubation for $30 \mathrm{~min}$ at room temperature. The sections were mounted in PermaFlior ${ }^{\mathrm{TM}}$ Aqueous Mounting Medium (ThermoShandon, PA, USA) and examined with a MRC-1024 confocal imaging system (BIO-RAD, Herts, UK).

\section{Statistical analysis}

As the expression of mRNAs for type I collagen, type III collagen, TGF- $\beta$, CTGF, aFGF, bFGF, PDGF A, PDGF C and EGF exhibited asymmetrical distributions, nonparametric tests (Wilcoxon paired tests) were used. The relationship between expression of collagens and TGF- $\beta$, CTGF, aFGF, bFGF, PDGF A, PDGF C and EGF was assessed by linear regression analysis (Mann-Whitney $U$ test). Significance was defined as $P<0.05$. Statistical calculations were performed with the Stat View software package (Version 5.0: Abacus Concepts, Inc., Berkeley, CA, USA).
Table 3 Expression of collagens and potent desmoplastic inducing growth factors

\begin{tabular}{|c|c|c|c|}
\hline Gene & & $\begin{array}{l}\text { total } \times 10^{2} \text { copies } / \\
\text { RNA }\end{array}$ & $P$-value \\
\hline Type I collagen & $\begin{array}{l}\mathrm{C} \\
\mathrm{N}\end{array}$ & $\begin{array}{r}2497.1 \pm 3322.7 \\
864.6 \pm 1087.4\end{array}$ & 0.018 \\
\hline Type III collagen & $\begin{array}{l}\mathrm{C} \\
\mathrm{N}\end{array}$ & $\begin{array}{r}2103.1 \pm 2305.7 \\
876.0 \pm 1143.8\end{array}$ & 0.018 \\
\hline TGF- $\beta$ & $\begin{array}{l}\mathrm{C} \\
\mathrm{N}\end{array}$ & $\begin{array}{c}12.9 \pm 15.2 \\
3.8 \pm 3.9\end{array}$ & 0.026 \\
\hline aFGF & $\begin{array}{l}\mathrm{C} \\
\mathrm{N}\end{array}$ & $\begin{array}{l}4.1 \pm 5.4 \\
1.1 \pm 2.5\end{array}$ & 0.002 \\
\hline bFGF & $\begin{array}{l}\mathrm{C} \\
\mathrm{N}\end{array}$ & $\begin{array}{l}4.6 \pm 6.5 \\
1.8 \pm 2.2\end{array}$ & 0.034 \\
\hline PDGF C & $\begin{array}{l}\mathrm{C} \\
\mathrm{N}\end{array}$ & $\begin{array}{r}14.9 \pm 23.7 \\
5.3 \pm 11.0\end{array}$ & 0.028 \\
\hline CTGF & $\begin{array}{l}\mathrm{C} \\
\mathrm{N}\end{array}$ & $\begin{array}{r}212.8 \pm 380.3 \\
96.9 \pm 159.7\end{array}$ & 0.170 \\
\hline PDGF A & $\begin{array}{l}\mathrm{C} \\
\mathrm{N}\end{array}$ & $\begin{array}{l}3.4 \pm 3.1 \\
3.9 \pm 5.3\end{array}$ & 0.347 \\
\hline EGF & $\begin{array}{l}\mathrm{C} \\
\mathrm{N}\end{array}$ & $\begin{array}{l}1.3 \pm 3.1 \\
3.1 \pm 5.1\end{array}$ & 0.179 \\
\hline
\end{tabular}

$\mathrm{C}=$ cancerous lesions, $\mathrm{N}=$ noncancerous lesions.

\section{RESULTS}

\section{Expression of mRNAs for collagens and growth factors in surgical specimens}

mRNA copy numbers are listed in Table 3 and represented in Figure 1. In surgically resected pancreatic cancerous lesions $(=C)$, the expression of mRNA for type I collagen and type III collagen was significantly higher (2.9- and 2.4-fold, respectively) compared to non-neoplastic pancreatic tissues $(=\mathrm{N})$ (Table 3, Figure 1A). The expression of mRNA for TGF- $\beta$ in $C$ was also higher (3.4-fold) than that in N (Figure 1B). The expression of mRNA for aFGF (3.7fold), bFGF (2.6-fold), PDGF C (2.8-fold) and CTGF (2.2-fold) was also higher in cancer tissue, while that for PDGF A ( -1.1 -fold) and EGF (-2.5-fold) was lower (Figure 1B). All growth factors with upregulated expression correlated with type I and type III collagen gene expression. (Type I collagen: TGF- $\beta(r=0.684, P=0.0003)$, CTGF $(r=0.436, P=0.0376)$, aFGF $(r=0.245, P=0.2591)$, bFGF $(r=0.119, P=0.3206)$, PDGF C $(r=0.562, P=0.0052)$, Type III collagen: TGF- $\beta \quad(r=0.727, \quad P<0.0001), \quad$ CTGF $\quad(r=0.624$, $P=0.0015), \quad$ aFGF $\quad(r=0.482, \quad P=0.02), \quad$ bFGF $\quad(r=0.164$, $P=0.4547)$, PDGF $C(r=0.562, P=0.0007))$. These results indicated that the expression of TGF- $\beta$ showed high correlation with the expression of type I collagen (Figure 2A) and type III collagen (Figure 2B).

\section{Type I and type III collagen and TGF- $\beta$ mRNA expression in cell lines}

The copy numbers of the collagens and TGF- $\beta$ mRNA per $100 \mathrm{ng}$ total RNA were analysed for various cell lines. The expression of mRNA for the collagens in fibroblast cell lines was prominent, while the pancreatic cancer cell lines were nearly negative for expression 
A
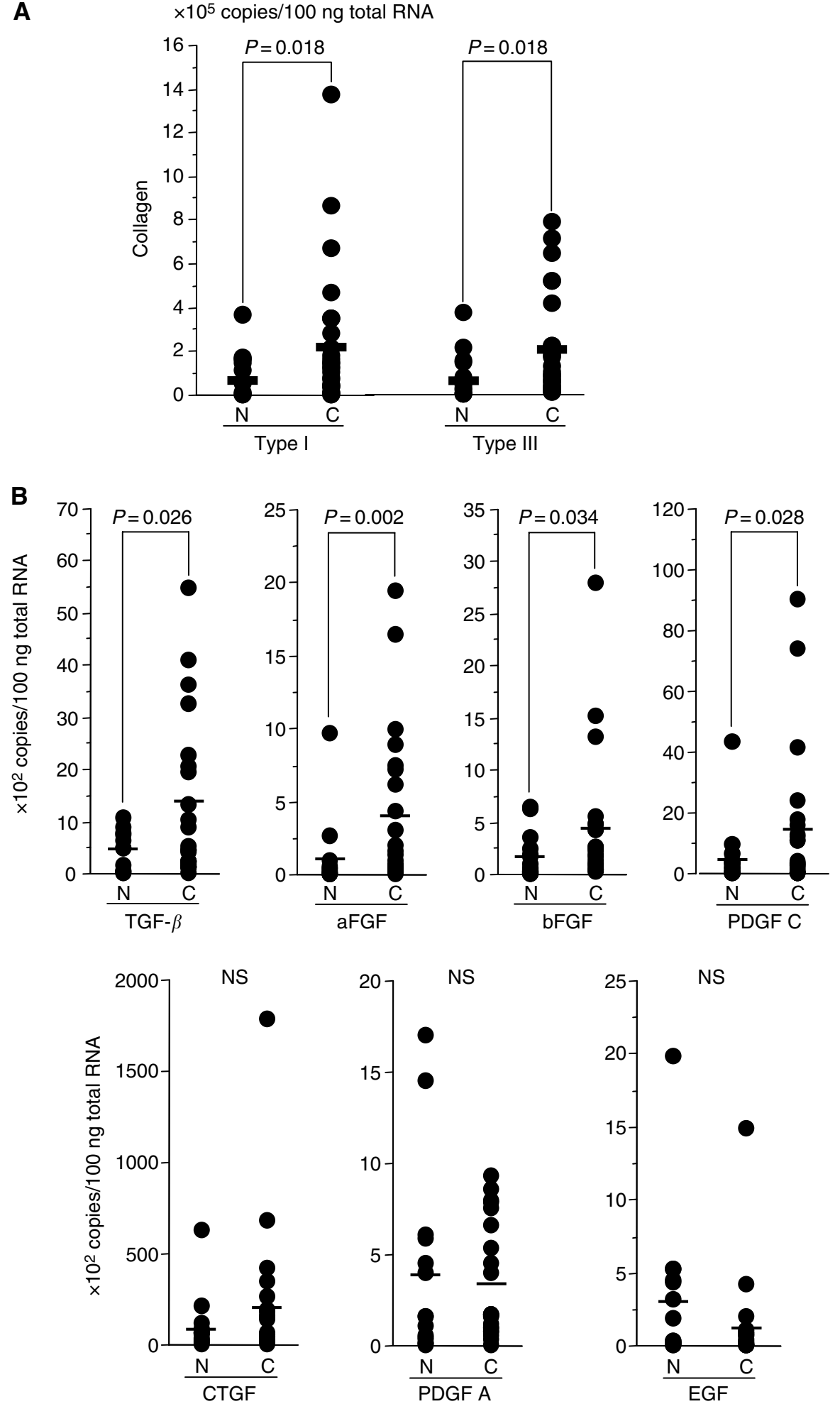

Figure I Expressed copy number per $100 \mathrm{ng}$ of total RNA in pancreatic cancerous (C) and noncancerous ( $N$ ) lesions from surgical specimens as measured by real-time RT-PCR. (A) Expressions of type I collagen and type III collagen in C were significantly higher than that of N. (B) Expressions of TGF- $\beta$, aFGF, bFGF and PDGF C in C were significantly higher than that of N, while those of CTGF, PDGF A and EGF were not significant. Bars indicate mean values. NS: not significant.

(Figure 3A). This suggests that fibroblasts may play a crucial role in collagen production, rather than pancreatic cancer cells. Expression of TGF- $\beta$ is not a specific characteristic of pancreatic cancer cell lines and, in fact, cell lines originating from fibroblasts, gastric cancer and colon cancers also express TGF- $\beta$ mRNA at the same or higher levels as the pancreatic cancer cell lines (Figure 3B). 
A $\times 10^{5}$ copies $/ 100$ ng total RNA

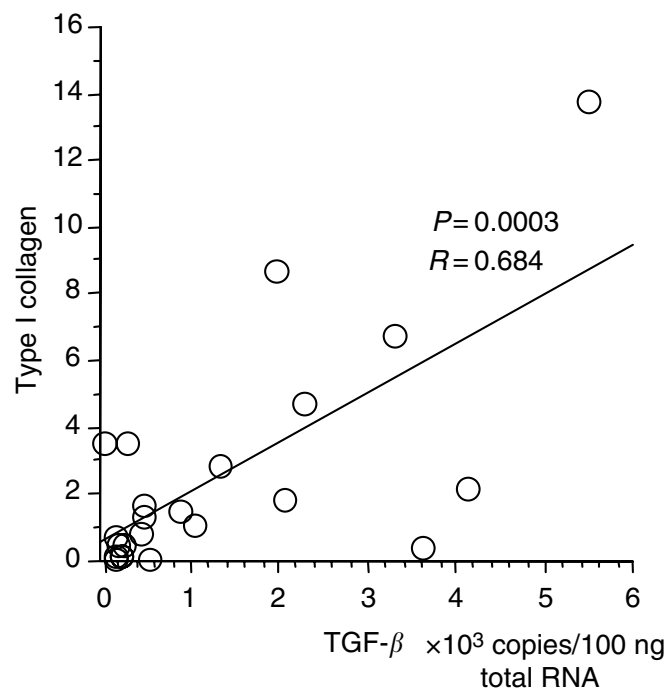

B $\times 10^{5}$ copies $/ 100 \mathrm{ng}$ total RNA

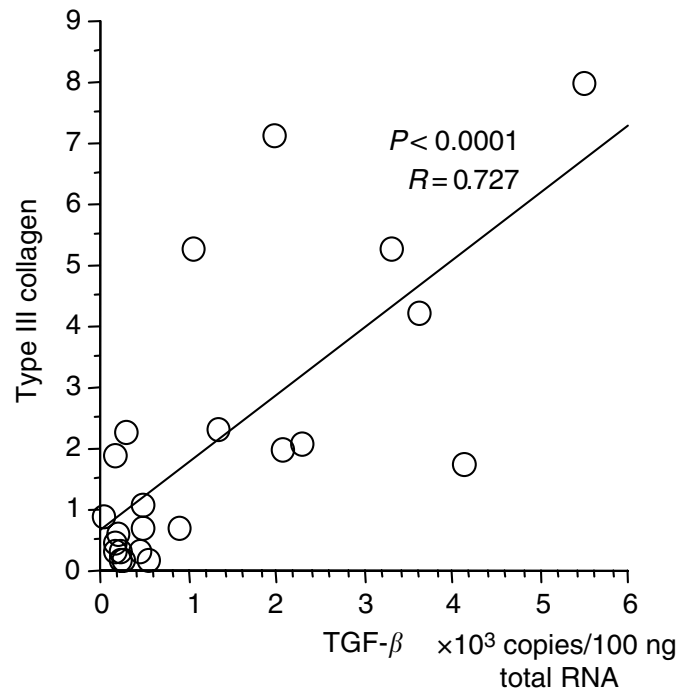

Figure 2 Correlation between TGF- $\beta$ and type I collagen (A), and TGF$\beta$ and type III collagen (B) mRNA expression in surgical specimens. The expressed copy number of TGF- $\beta$ and collagens in pancreatic cancer tissues from surgical specimens showed a correlation.

\section{Immunolocalisation of TGF- $\beta$}

Since the expression of TGF- $\beta$ mRNA showed a prominent correlation with the expression of collagen mRNA, the protein distribution of TGF- $\beta$ in pancreatic cancer tissues was examined using immunohistochemistry. Immunohistochemistry with TGF- $\beta$ (Figure 4) demonstrated that the staining in pancreatic cancer cells was extremely faint positive at short $\mathrm{DAB}$ reaction times $(\approx 1 \mathrm{~min})$ (arrows in Figures $4 \mathrm{~A}$ and $\mathrm{B}$ ), and was barely recognisable after longer incubation $(\approx 10 \mathrm{~min}$ ) (arrows in Figures $4 \mathrm{C}$ and $\mathrm{D}$ ). In contrast, highly prominent immunostaining was observed in isolated cells bordering the cancer nests even at short $\mathrm{DAB}$ reaction times (arrow heads in Figures 4A and B). These TGF- $\beta$ positive cells were predominantly distributed at the invasive front area (or tumour periphery) (Figures $4 \mathrm{~A}$ and $\mathrm{C}$ ), but were rare in the tumour core (Figures $4 \mathrm{~B}$ and D). High-power field observation
A $\times 10^{5}$ copies $/ 100 \mathrm{ng}$ total RNA

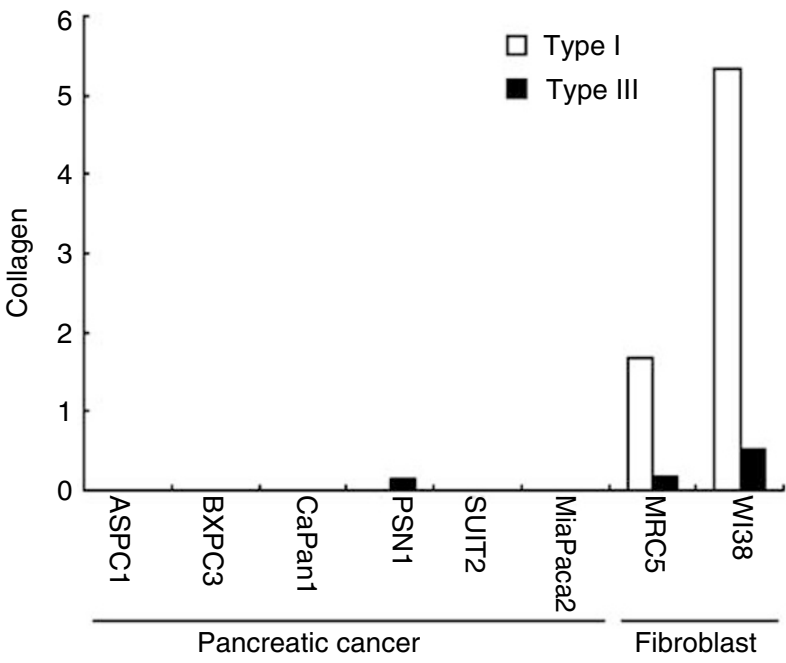

B $\times 10^{3}$ copies $/ 100$ ng total RNA

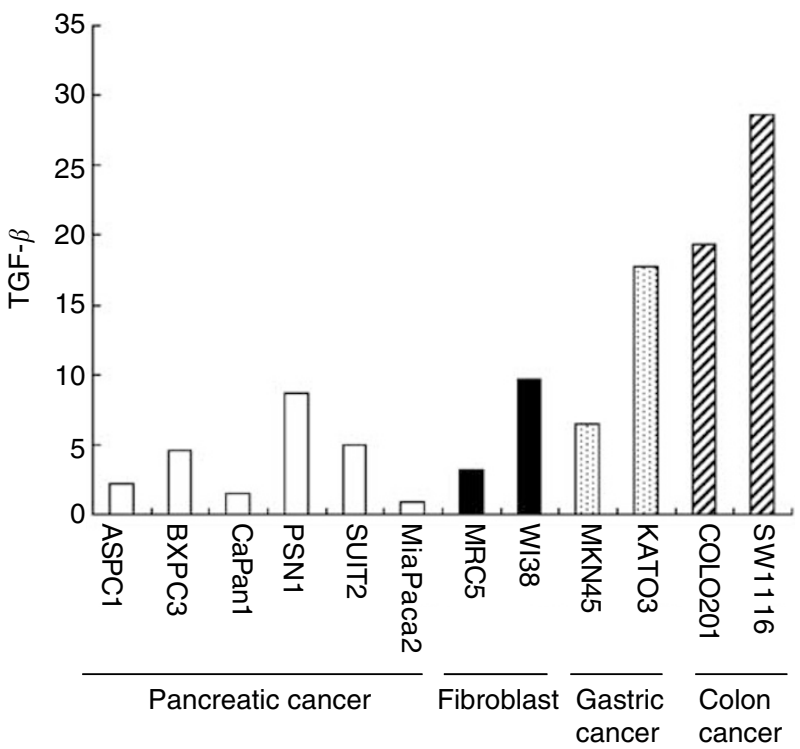

Figure 3 Expression of collagens and TGF- $\beta$ mRNA in various cancer cell lines. (A) Expressions of type I and type III collagens were negative in pancreatic cancer cells, except for a small amount of type III in PSNI compared with fibroblasts. (B) Since the expression of TGF- $\beta$ in pancreatic cancer cell lines was the same or less than that in fibroblasts, gastric cancer and colon cancer cell lines, it was presumed that TGF- $\beta$ overexpression is not a specific feature for pancreatic cancer cells.

of these cells revealed that they possessed bandform and/or segmented nuclei and were presumed to be haematopoietic granulocytes (Figures $4 \mathrm{~A}$ and $\mathrm{C}$ ). Immunohistochemistry with anti-GFP rabbit polyclonal antibodies demonstrated complete negative staining for these isolated cells (Figures $4 \mathrm{E}$ and $\mathrm{F}$ ), demonstrating that immunostaining with anti-TGF- $\beta$ was not an artefact but a result of true immuno-reaction between antigens. The other stromal components such as fibroblasts and endothelial cells showed only weak or no immunostaining (Figure 4).

$\mathrm{CD} 68+$ macrophages and antigranulocyte antibody-positive granulocyte cells were also distributed in the area surrounding the cancer nests, similar to the distribution of TGF- $\beta$-positive cells 

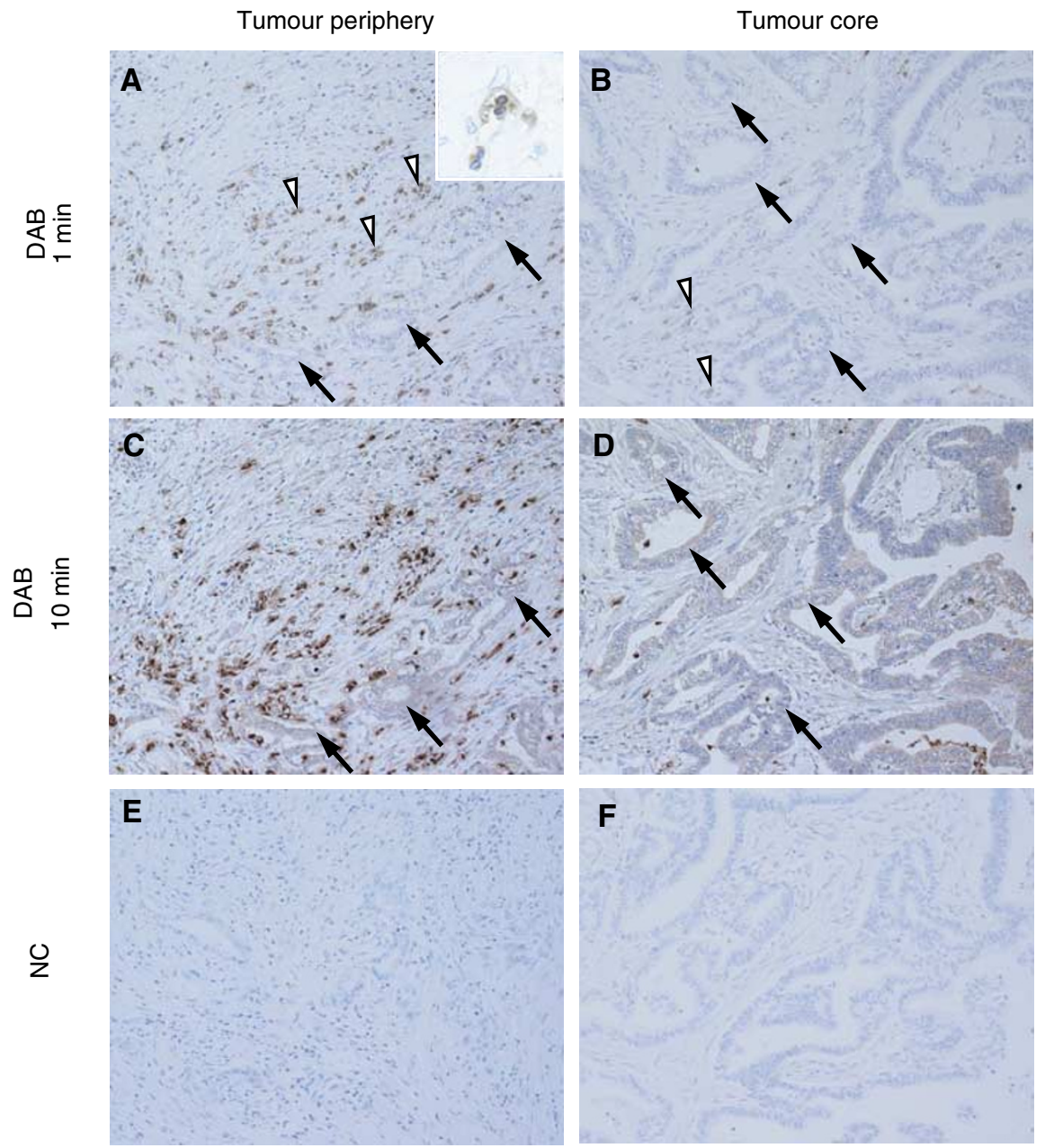

Figure 4 TGF- $\beta$ immunohistochemistry in pancreatic adenocarcinoma. Transforming growth factor- $\beta$ immunostaining was visualised by short ( $\approx$ I min) and long $(\approx 10 \mathrm{~min})$ reactions with DAB. Note that staining for cancer cells is barely visible at short DAB staining times (closed arrows) in both the tumour periphery $(\mathbf{A})$ and core $(\mathbf{B})$, and only slightly apparent after a I0-min reaction (closed arrows) in both the tumour periphery (C) and core (D). Intense TGF$\beta$ immunoreactivity was found in granular cells adjacent to the pancreatic cancer nests, even at short DAB incubation periods (open arrow heads) (A, B). These TGF- $\beta$-positive cells were predominantly observed at the tumour periphery $(\mathbf{A})$, and are rare in the tumour core $(\mathbf{B})$. Immunohistochemistry using anti-GFP rabbit polyclonal antibodies as a negative control against anti-TGF- $\beta$ rabbit polyclonal antibody resulted in negative staining in both the tumour periphery $(\mathbf{E})$ and core $(\mathbf{F})$. NC: negative control.

(Figure 5). High-power field observation of these CD68+ macrophages had a single nucleus, while the antigranulocyte antibody-positive granulocyte cells harboured segmented nuclei. Thus, the cells that overexpress TGF- $\beta$ can be confidently identified as granulocytes. Moreover, in gastric and colon cancer tissues, isolated cells with segmented nuclei around cancer nests at the invasive front also showed strong staining for TGF- $\beta$ (Figure 6).

\section{Double immunofluorescence stain, (TGF- $\beta+$ CD68) or (TGF- $\beta$ + granulocyte)}

In order to unambiguously identify the cells producing TGF- $\beta$ in pancreatic cancer tissues, double immunofluorescence staining was carried out. Distribution of TGF- $\beta$-positive cells did not correlate with the distribution of $\mathrm{CD} 68+$ cells (Figures 7A-C). However, double staining with anti-TGF- $\beta$ and antigranulocyte antibodies showed clearly concordant results (Figures $7 \mathrm{D}-\mathrm{F}$ ). These results indicated that the major cellular source of TGF- $\beta$ in pancreatic tumour tissues, in addition to cancer cells, is granulocytes and not macrophages.

\section{Subtype of granulocytes by morphological observation}

In order to identify the subclass of TGF- $\beta$-producing granulocytes, careful microscopical observation for haematoxylin-eosin-staining sections was performed. Majorities of the granulocytes were presumed to be neutrophils. As shown in representative pictures in Figures $8 \mathrm{~A}$ and $\mathrm{B}$, these cells contain polymorphonucleus with cytoplasms stained pink, indicating their neutrophilic feature. Eosinophils, characterised by its distinctive cytoplasmic granules stained red (arrows in Figures 8C and D), were also noted, however, the population of this subtype should at most be $3-5 \%$ of entire granulocytes.

\section{DISCUSSION}

Comprehensive mRNA analysis of several growth factors in pancreatic cancer, including TGF- $\beta$, CTGF, aFGF, bFGF, PDGF $\mathrm{A}, \mathrm{PDGF} \mathrm{C}$ and EGF, resulted in the finding that TGF- $\beta$ is likely to be a potent inducer of the desmoplastic reaction. Furthermore, 

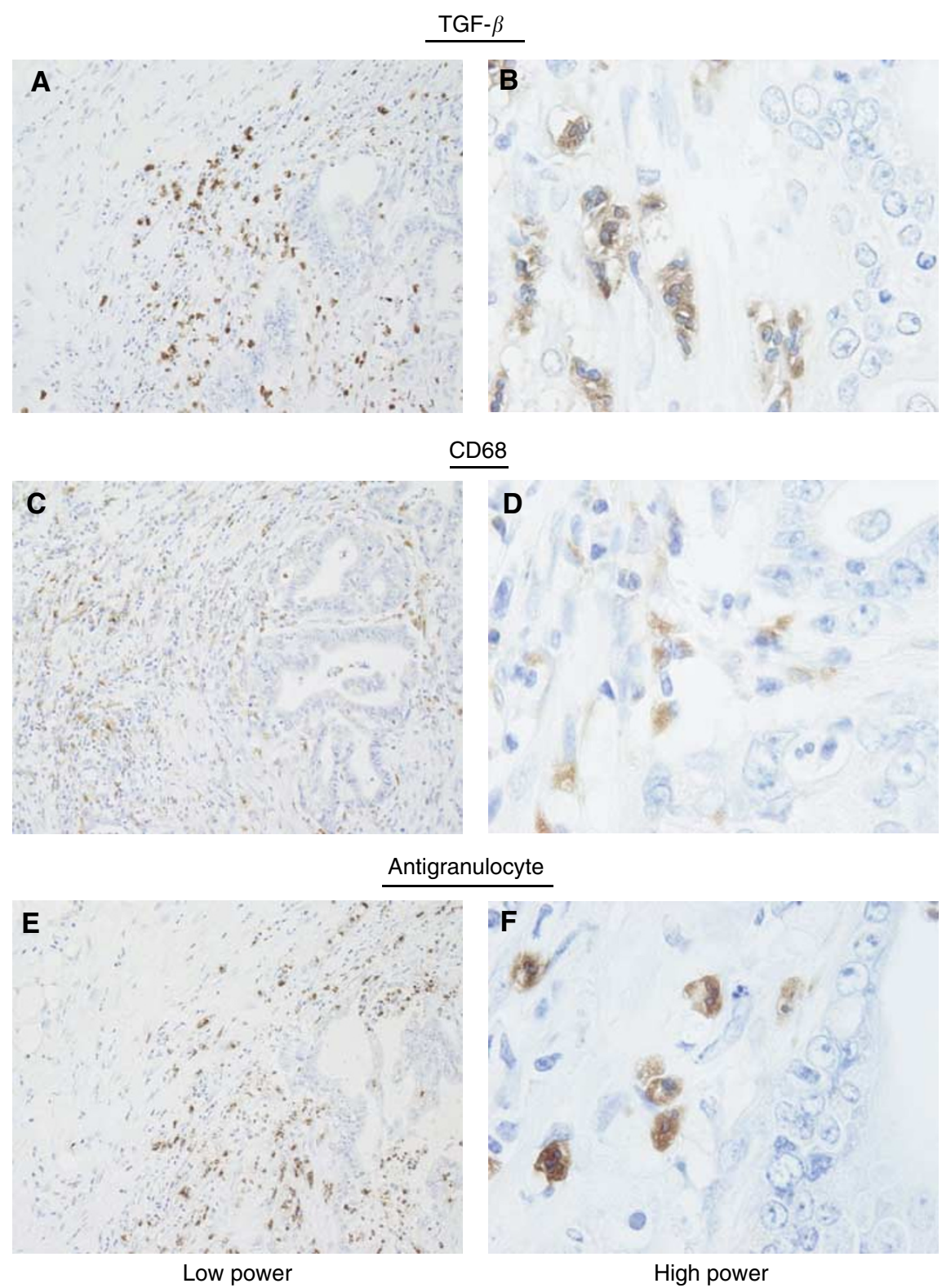

Figure 5 Distribution of TGF- $\beta$, CD68 and antigranulocyte-positive cells in pancreatic adenocarcinoma. The distribution of isolated TGF- $\beta$-positive cells in pancreatic cancer $(\mathbf{A})$ was similar to that of macrophage (i.e. CD68 + cells) $(\mathbf{C})$ and granulocytes $(\mathbf{E})$ in low power field observation. However, in high power field observation, the morphology of TGF- $\beta$ I-positive isolated cells (B) coincided with antigranulocyte-positive segmented nucleus cells (F) but not CD68 + mononuclear cells $(\mathbf{D})$.

infiltrated granulocytes (mostly are neutrophils) were highlighted as a predominant source of TGF- $\beta$.

In this study, we initially demonstrated that the expression of type I and type III collagens in pancreatic cancer tissues was at least three-fold higher than that in normal pancreatic tissue (Figure 1A), confirming previous reports (Gress et al, 1995; Imamura et al, 1995; Linder et al, 2001). The origin of type I and type III collagens mRNA has been assumed to be cancer stroma (Gress et al, 1995), a finding supported by our studies in pancreatic cancer cell lines. Indeed, cancer cells are capable of synthesis and production of extracellular matrix proteins (Niitsu et al, 1988; Yoshida et al, 1989; Lohr et al, 1994), although the expression of collagen mRNAs in the pancreatic cancer cell lines was somewhat lower in comparison to that of fibroblast cell lines (Figure 3A). Furthermore, the expression of collagens from pancreatic cancer cells does not increase in vivo, that is, subcutaneous xenotransplantation in immunodeficient mice (unpublished data).

In order to better understand the molecular mechanisms underlying the stromal reaction, we examined the levels of several growth factors capable of inducing desmoplasia. Though plural molecules including TGF- $\beta$, aFGF, bFGF and PDGF $\mathrm{C}$ were overexpressed in pancreatic cancer (Figure 1B) and presumed to be associated with desmoplasia, we focused on TGF- $\beta$ since its expression showed the most significant correlation with that of collagens. The expression of TGF- $\beta$ in pancreatic cancer tissue was actually 3.5 -fold higher than that found in normal pancreatic regions (Figure 1B). These results correlate with that of Friess et al (1993), who previously reported similar semiquantitative results by Northern blot analysis and/or in situ hybridisation. Other authors have reported on the overexpression of TGF- $\beta$ in various cancer 

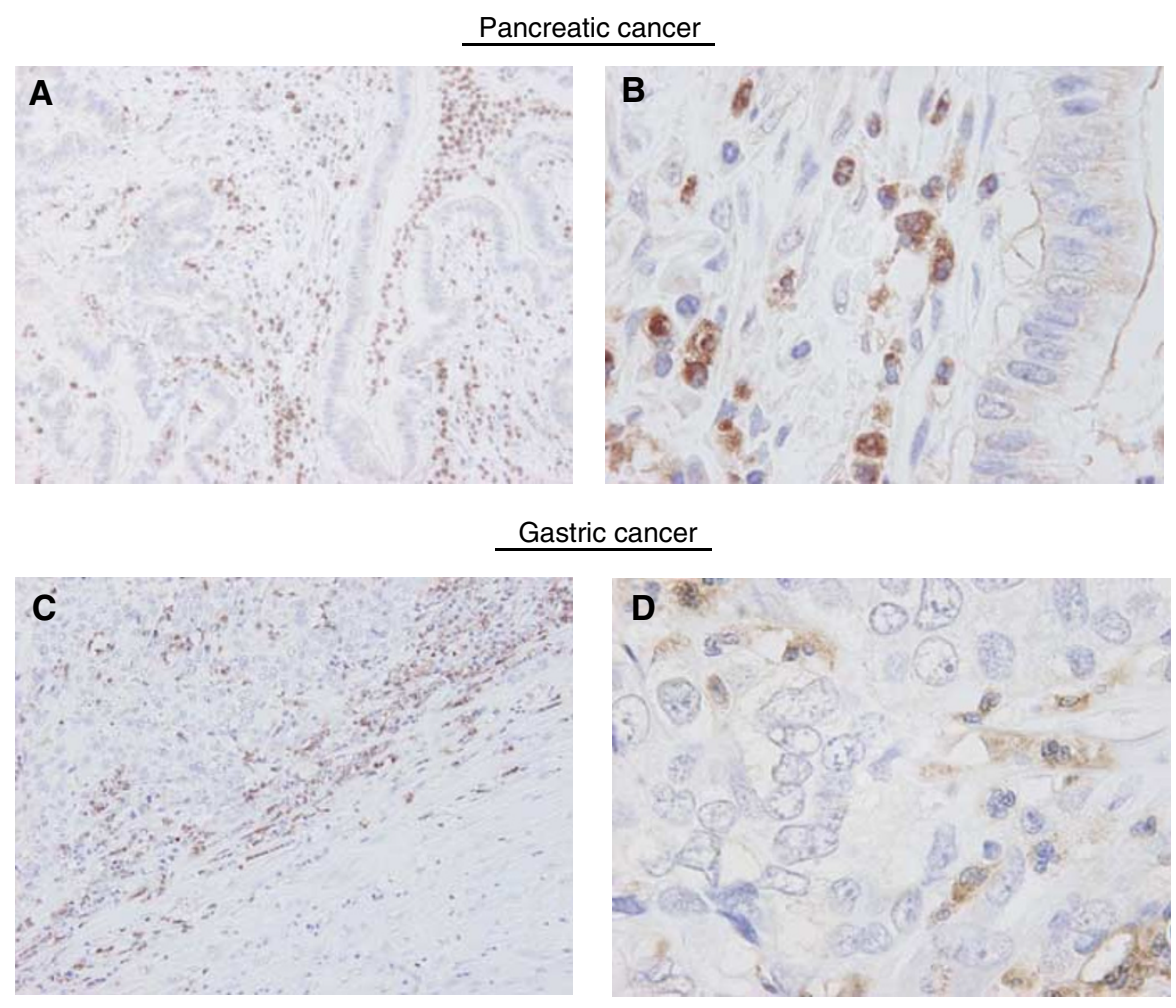

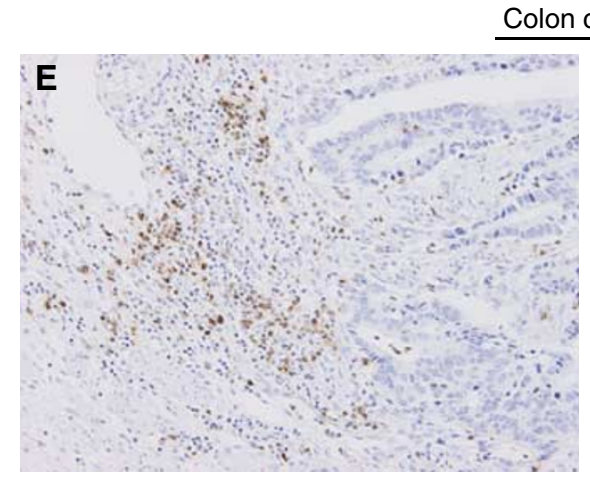

Low power

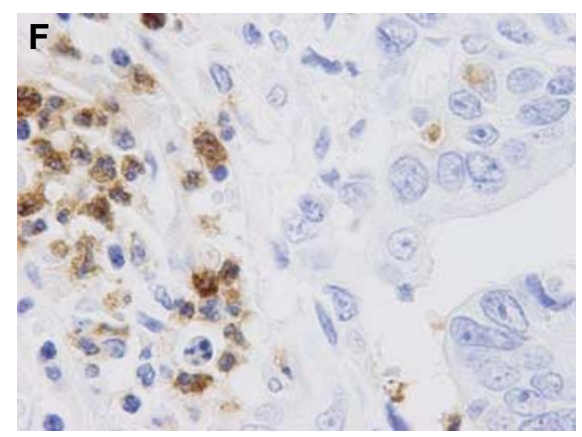

High power

Figure 6 TGF- $\beta$ immunoreactivity in pancreatic, gastric, and colon cancer tissues. TGF- $\beta$ immunoreactivity was found in isolated cells around cancer nests in pancreatic cancer tissue $(\mathbf{A})$ and many of these cells harboured segmented nuclei $(\mathbf{B})$. Transforming growth factor- $\beta$-positive segmented nuclei cells were likewise observed in gastric $(\mathbf{C}, \mathbf{D})$ and colon $(\mathbf{E}, \mathbf{F})$ cancers, especially in the tumour periphery. Low power field $(\mathbf{A}, \mathbf{C}, \mathbf{E})$. High power field $(\mathbf{B}$, D, F).

types by immunohistochemistry, Northern blot analysis and/or in situ hybridisation (Samuels et al, 1989; Yoshida et al, 1989; BarrettLee et al, 1990; Gorsch et al, 1992; Walker and Dearing, 1992; Mahara et al, 1994), although none of these methods were quantitative. Our results extend these earlier studies by providing independent, quantitative analysis of the overexpression of TGF- $\beta$ in pancreatic cancer by employing real-time RT-PCR methods.

While the expressions of both TGF- $\beta$ and collagens have been examined independently, their expressions relative to one another have not been considered. The utilisation of quantitative RT - PCR method enabled us to evaluate the correlation between the expressions of TGF- $\beta$ mRNA and collagens. Both in vitro and in vivo experimental evidence has been accumulating, showing that TGF- $\beta$ stimulates the production of collagens from fibroblasts. In fact, cultured fibroblasts increased the production of collagen from three- to five-fold when incubated with appropriate concentrations of TGF- $\beta$ (Raghow et al, 1987; Varga et al, 1987). When TGF- $\beta$ was directly injected into the subcutaneous tissue of newborn mice, accelerated fibrosis, that is, activation of fibroblasts to produce collagens, was demonstrated (Roberts et al, 1986; Shinozaki et al, 1997). In clinical diseases including pulmonary fibrosis and chronic renal allograft damage, TGF- $\beta$ is also considered to be a main pathogenic factor for the overproduction of collagen (Nicholson et al, 1999). Obviously, TGF- $\beta$ is not the only factor that can stimulate collagen expression in fibroblasts, since insulin and/or growth factors analysed here also regulate the production of type I collagen (Krupsky et al, 1996). Nonetheless, it can be stated here that TGF- $\beta$ may be one of the main inducers of the desmoplastic reaction in pancreatic cancer.

One question concerns the cellular origin of TGF- $\beta$ in pancreatic cancer nodules. Previous reports have indicated that the upregulated TGF- $\beta$ originated from cancer cells, since 

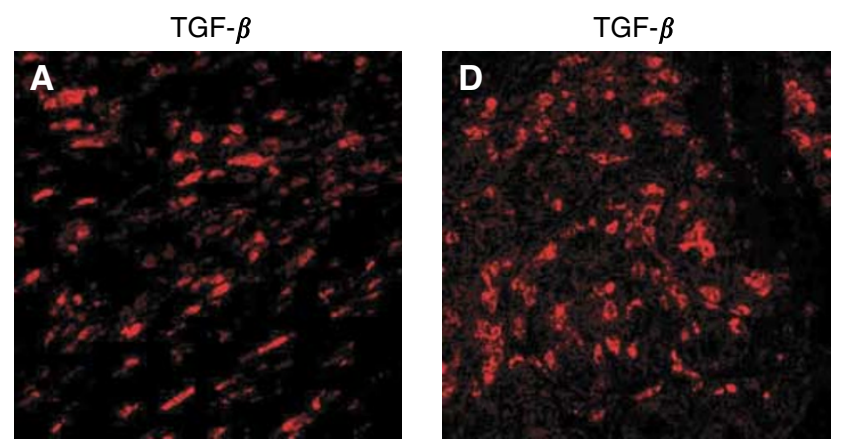

CD68
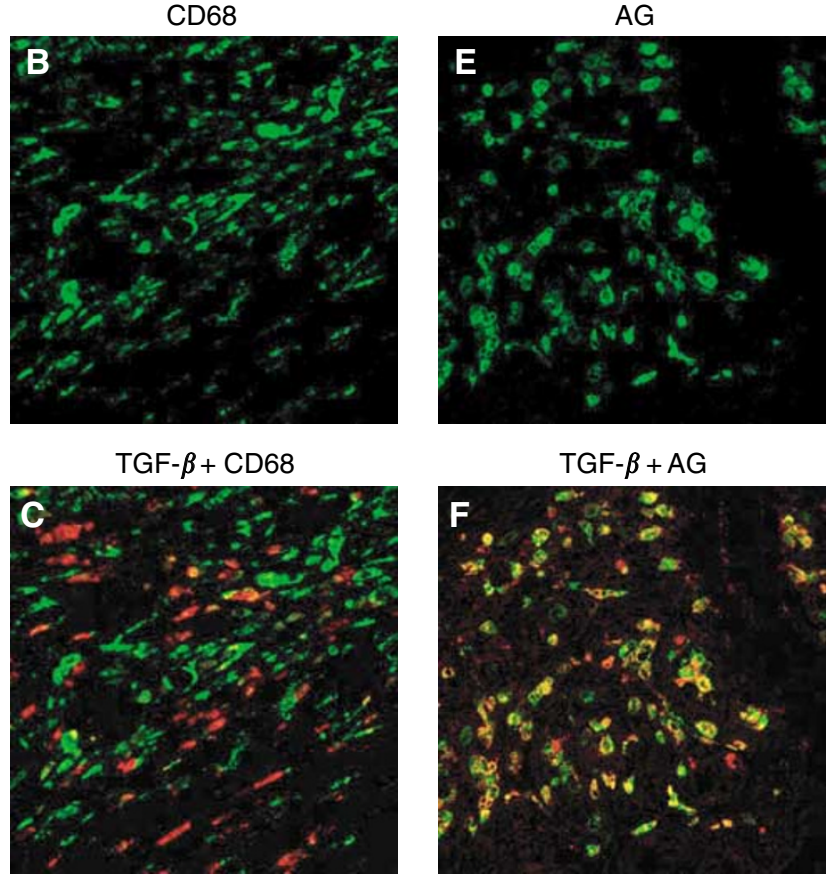

Figure 7 Confocal immunofluorescence images showing TGF- $\beta$ (red) (A, D), CD68 as a marker of macrophages (green) (B) and granulocytes (green) (E). Transforming growth factor- $\beta$ staining was topographically different from the staining of CD68 + cells $(\mathbf{C})$. However, double staining with anti-TGF- $\beta$ and antigranulocyte antibodies resulted in a consistent overlap (F). AG: antigranulocyte.

immunohistochemical and/or in situ hybridisation studies demonstrated that the TGF- $\beta$ s were localised in tumour cytoplasm (Friess et al, 1993; Coppola et al, 1998). However, it must be considered that the proportion of cancer cells in pancreatic cancer nodules is rather low $(20-30 \%$ at the highest) as a result of desmoplastic reaction (Kloppel et al, 1985). If indeed these cancer cells were the origin of overexpressed TGF- $\beta$ in pancreatic cancer nodules, each cancer cell would be expected to show prominent TGF- $\beta$ staining. However, our immunohistochemical study for TGF- $\beta$ demonstrated only faint cytoplasmic staining in cancer cells even after a 10-min reaction with DAB (Figure 4D). In contrast, isolated cells in the surrounding stroma of the cancer nests showed prominent positive staining even after short $(1 \mathrm{~min}) \mathrm{DAB}$ reaction times (Figure 4A). Initially, we assumed that this staining might be due to artefactual staining by endogenous peroxidase. However, staining without incubation of primary antibodies resulted in negative staining for these cells. A second possibility for falsepositive staining could also be nonspecific binding of the Fc fragment or trapping of antibody in these isolated cells. In order to rule out this possibility, we carried out incubation with the first antibody with the same type of antibody against an antigen that is not expressed in human tissues, that is, polyclonal rabbit antibody against anti-GFP. Again, this negative control resulted in no staining in these isolated cells (Figures $4 \mathrm{E}$ and $\mathrm{F}$ ). We are therefore confident that the isolated cells in stroma surrounding the cancer nest are actually strongly positive for TGF- $\beta$.

It then remained to determine the identity of the cells that overexpress TGF- $\beta$. We initially postulated that these cells were macrophages, since it has been reported that macrophages can secrete TGF- $\beta$ (Assoian et al, 1987; Appleton et al, 1993) and, moreover, that the expression of TGF- $\beta$ is associated with fibroblast collagen synthesis (Khalil et al, 1989). However, while the distribution of TGF- $\beta$-positive cells and CD68 + cells was somewhat similar, double-staining IHC did not show consistent double staining with these two antibodies (Figure 6). We then focused on granulocytes, since these cells, including neutrophils and eosinophils, have also been reported to express TGF- $\beta$ (Grotendorst et al, 1989; Wong et al, 1991). Moreover, in the acute phase of disease, neutrophil granulocytes have been shown to express higher amounts of TGF- $\beta$ mRNA with respect to lymphocytes and monocytes/macrophages (Ossege et al, 1996). Furthermore, the TGF- $\beta$ produced by eosinophils has been shown to be involved in connective tissue remodelling and collagen synthesis (Stahle-Backdahl et al, 2000; Nomura et al, 2002). As shown in Figure 7, these TGF- $\beta$-positive cells coincided extremely well with that of antigranulocyte antibody-positive cells, and morphological evidence supported a notion that majorities of these cells were neutrophils (Figure 8). Together with previous reports that TGF- $\beta$ is distributed in stromal inflammatory cells including granulocytes as well as cancer cells (Roberts et al, 1986; Assoian et al, 1987), it seems reasonable to regard that the predominant source of high levels of TGF- $\beta$ may be infiltrating neutrophil, though bulk tumoral TGF- $\beta$ should be accumulation of that from neutrophils, eosinophils and cancer cells. A precise and conclusive cellular source of TGF- $\beta$ in a tumoral context, however, remains to be identified through in situ hybridisation.

Neutrophil infiltration is a biological phenomenon that is usually associated with acute inflammation such as bacterial infection. The present pancreatic cancer population was basically free from sign of acute pancreatitis showing high serum amylase level at the time of operation. Furthermore, resected specimens demonstrated no sign of infection such as the presence of pus. We believe that this neutrophil infiltration observed in the present study may be an important phenomenon that should be focused in understanding pancreatic cancer progression. Observation of only the central core of the pancreatic cancer may have missed this neutrophil infiltration, as we demonstrated in Figure 4 . In order to evaluate whether infiltration of granulocytes overexpressing TGF- $\beta$ is specific to pancreatic cancer, we performed immunostaining for TGF- $\beta$ on gastric and colon cancer samples. As shown in Figure 6, TGF- $\beta$-positive granulocytes are clearly present, especially at the invasive front. Thus, TGF- $\beta$-secreting infiltrating granulocytes are present in pancreatic, gastric and colon cancer; however, a prominent desmoplastic reaction is observed only in the former. This apparent discrepancy may be explained by the mechanism of activation of TGF- $\beta$. Transforming growth factor- $\beta$ is generally released from cells in a latent, biologically inactive form (Miyazono et al, 1993). Following release, it is activated by a variety of mechanisms, including exposure to proteolytic enzymes or alkaline pH conditions (Gleizes et al, 1997; Khalil, 1999). The presence of proteases in the pancreas and the alkaline $\mathrm{pH}$ of pancreatic juice may result in ideal conditions for activation of latent TGF- $\beta$.

In conclusion, we demonstrated that TGF- $\beta$ is overexpressed in pancreatic cancer nodules and, moreover, that TGF- $\beta$ is secreted mainly by infiltrating granulocytes (mostly are neutrophils) and not cancer cells. Once secreted, TGF- $\beta$ can be activated in the unique pancreatic environment, thereby stimulating fibroblasts to 

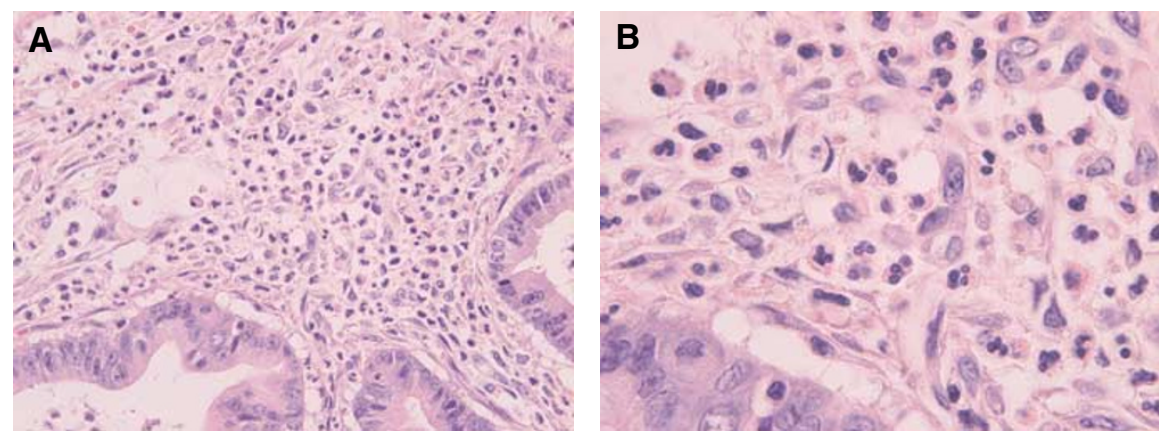

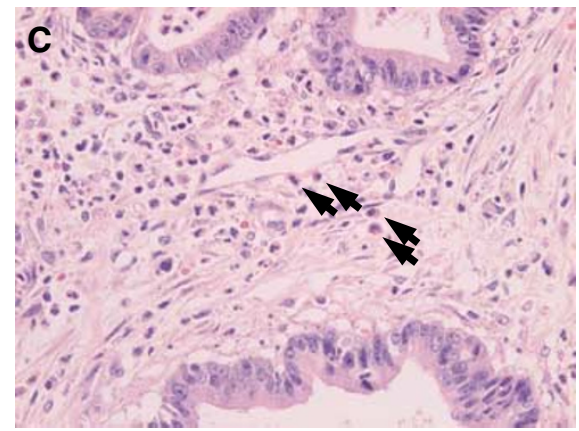

Low power

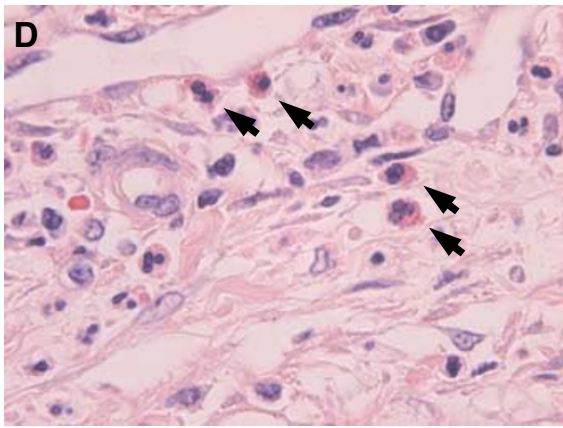

High power

Figure 8 Morphological demonstration of infiltrated granulocytes in pancreatic cancer in Haematoxylin-eosin section. (A, B) Majorities of isolated cells in stromal, that was the precipitated area of TGF- $\beta$-staining positive cells, harboured segmented or polymorpho nuclei with neutrally stained cytoplasmic granules, indicating their neutrophilic nature. (C, D) Bilobed or trinuclei cells with acidic stained granules (= red), characteristic presentation of eosinophils, are also observed, but the proportion of these cells was at most $3-5 \%$ of the entire granulocyte. Low power field $(\mathbf{A}, \mathbf{C})$. High power field $(\mathbf{B}, \mathbf{D})$.

produce collagens. In order to interfere with this desmoplastic reaction in pancreatic cancer, a greater understanding and control of the phenomenon of granulocyte infiltration, and control of subsequent activation mechanisms of TGF- $\beta$, is urgently required. Furthermore, the meaning of neutrophils infiltration in pancreatic cancer progression, that is, whether it is associated with better or worse prognosis, remains to be elucidated.

\section{REFERENCES}

Appleton I, Tomlinson A, Colville-Nash PR, Willoughby DA (1993) Temporal and spatial immunolocalisation of cytokines in murine chronic granulomatous tissue. Implications for their role in tissue development and repair processes. Lab Invest 69: 405-414

Assoian RK, Fleurdelys BE, Stevenson HC, Miller PJ, Madtes DK, Raines EW, Ross R, Sporn MB (1987) Expression and secretion of type beta transforming growth factor by activated human macrophages. Proc Natl Acad Sci USA 84: 6020-6024

Barrett-Lee P, Travers M, Luqmani Y, Coombes RC (1990) Transcripts for transforming growth factors in human breast cancer: clinical correlates. Br J Cancer 61: 612-617

Coppola D, Lu L, Fruehauf JP, Kyshtoobayeva A, Karl RC, Nicosia SV, Yeatman TJ (1998) Analysis of p53, p21WAF1, and TGF-beta1 in human ductal adenocarcinoma of the pancreas: TGF-betal protein expression predicts longer survival. Am J Clin Pathol 110: 16-23

Ebert M, Yokoyama M, Friess H, Kobrin MS, Buchler MW, Korc M (1995) Induction of platelet-derived growth factor $\mathrm{A}$ and $\mathrm{B}$ chains and overexpression of their receptors in human pancreatic cancer. Int $J$ Cancer 62: $529-535$

Fine A, Goldstein RH (1987) The effect of transforming growth factor-beta on cell proliferation and collagen formation by lung fibroblasts. $J$ Biol Chem 262: 3897-3902

Frazier K, Williams S, Kothapalli D, Klapper H, Grotendorst GR (1996) Stimulation of fibroblast cell growth, matrix production, and granulation

\section{ACKNOWLEDGEMENTS}

We thank C Okumura and Y Okuhara for their technical assistance. This investigation was supported in part by Cancer Research (11 - 12) from the Ministry of Health and Welfare of Japan, in part by Second Term Comprehensive 10-year Strategy for Cancer Control from the Ministry of Health and Welfare of Japan.

tissue formation by connective tissue growth factor. J Invest Dermatol 107: $404-411$

Friess H, Yamanaka Y, Buchler M, Ebert M, Beger HG, Gold LI, Korc M (1993) Enhanced expression of transforming growth factor beta isoforms in pancreatic cancer correlates with decreased survival. Gastroenterology 105: $1846-1856$

Gleizes PE, Munger JS, Nunes I, Harpel JG, Mazzieri R, Noguera I, Rifkin DB (1997) TGF-beta latency: biological significance and mechanisms of activation. Stem Cells 15: 190-197

Gold LI (1999) The role for transforming growth factor-beta (TGF-beta) in human cancer. Crit Rev Oncog 10: 303-360

Gorsch SM, Memoli VA, Stukel TA, Gold LI, Arrick BA (1992) Immunohistochemical staining for transforming growth factor beta 1 associates with disease progression in human breast cancer. Cancer Res 52: $6949-6952$

Gospodarowicz D (1983) Growth factors and their action in vivo and in vitro. J Pathol 141: $201-233$

Gress TM, Muller-Pillasch F, Lerch MM, Friess H, Buchler M, Adler G (1995) Expression and in-situ localisation of genes coding for extracellular matrix proteins and extracellular matrix degrading proteases in pancreatic cancer. Int J Cancer 62: 407-413

Grotendorst GR, Smale G, Pencev D (1989) Production of transforming growth factor beta by human peripheral blood monocytes and neutrophils. J Cell Physiol 140: 396-402 
Iacobuzio-Donahue CA, Ryu B, Hruban RH, Kern SE (2002) Exploring the host desmoplastic response to pancreatic carcinoma: gene expression of stromal and neoplastic cells at the site of primary invasion. Am J Pathol 160: $91-99$

Imamura $\mathrm{T}$, Iguchi $\mathrm{H}$, Manabe $\mathrm{T}$, Ohshio G, Yoshimura T, Wang ZH, Suwa H, Ishigami S, Imamura M (1995) Quantitative analysis of collagen and collagen subtypes I, III, and V in human pancreatic cancer, tumourassociated chronic pancreatitis, and alcoholic chronic pancreatitis. Pancreas 11: $357-364$

Khalil N (1999) TGF-beta: from latent to active. Microbes Infect 1: $1255-1263$

Khalil N, Bereznay O, Sporn M, Greenberg AH (1989) Macrophage production of transforming growth factor beta and fibroblast collagen synthesis in chronic pulmonary inflammation. J Exp Med 170: 727-737

Kloppel G, Lingenthal G, von Bulow M, Kern HF (1985) Histological and fine structural features of pancreatic ductal adenocarcinomas in relation to growth and prognosis: studies in xenografted tumours and clinicohistopathological correlation in a series of 75 cases. Histopathology 9: $841-856$

Korc M, Chandrasekar B, Yamanaka Y, Friess H, Buchier M, Beger HG (1992) Overexpression of the epidermal growth factor receptor in human pancreatic cancer is associated with concomitant increases in the levels of epidermal growth factor and transforming growth factor alpha. J Clin Invest 90: $1352-1360$

Krupsky M, Fine A, Kuang PP, Berk JL, Goldstein RH (1996) Regulation of type I collagen production by insulin and transforming growth factorbeta in human lung fibroblasts. Connect Tissue Res 34: 53-62

Leonardi A, Brun P, Tavolato M, Abatangelo G, Plebani M, Secchi AG (2000) Growth factors and collagen distribution in vernal keratoconjunctivitis. Invest Ophthalmol Vis Sci 41: 4175-4181

Linder S, Castanos-Velez E, von Rosen A, Biberfeld P (2001) Immunohistochemical expression of extracellular matrix proteins and adhesion molecules in pancreatic carcinoma. Hepatogastroenterology 48: $1321-1327$

Lohr M, Trautmann B, Gottler M, Peters S, Zauner I, Maillet B, Kloppel G (1994) Human ductal adenocarcinomas of the pancreas express extracellular matrix proteins. Br J Cancer 69: 144-151

Mahara K, Kato J, Terui T, Takimoto R, Horimoto M, Murakami T, Mogi Y, Watanabe N, Kohgo Y, Niitsu Y (1994) Transforming growth factor beta 1 secreted from scirrhous gastric cancer cells is associated with excess collagen deposition in the tissue. Br J Cancer 69: 777-783

McCartney-Francis NL, Wahl SM (1994) Transforming growth factor beta: a matter of life and death. J Leukoc Biol 55: 401-409

Miyazono K, Ichijo H, Heldin CH (1993) Transforming growth factor-beta: latent forms, binding proteins and receptors. Growth Factors 8: 11-22

Neoptolemos JP, Cunningham D, Friess H, Bassi C, Stocken DD, Tait DM, Dunn JA, Dervenis C, Lacaine F, Hickey H, Raraty MG, Ghaneh P, Buchler MW (2003) Adjuvant therapy in pancreatic cancer: historical and current perspectives. Ann Oncol 14: 675-692

Nicholson ML, Bicknell GR, Barker G, Doughman TM, Williams ST, Furness PN (1999) Intragraft expression of transforming growth factor betal gene in isolated glomeruli from human renal transplants. Br J Surg 86: $1144-1148$

Niitsu Y, Ito N, Kohda K, Owada M, Morita K, Sato S, Watanabe N, Kohgo Y, Urushizaki I (1988) Immunohistochemical identification of type I procollagen in tumour cells of scirrhous adenocarcinoma of the stomach. Br J Cancer 57: 79-82

Nomura A, Uchida Y, Sakamoto T, Ishii Y, Masuyama K, Morishima Y, Hirano K, Sekizawa K (2002) Increases in collagen type I synthesis in asthma: the role of eosinophils and transforming growth factor-beta. Clin Exp Allergy 32: $860-865$

Ossege LM, Sindern E, Voss B, Malin JP (1996) Expression of tumour necrosis factor-alpha and transforming growth factor-beta 1 in cerebrospinal fluid cells in meningitis. J Neurol Sci 144: 1-13

Powers CJ, McLeskey SW, Wellstein A (2000) Fibroblast growth factors, their receptors and signaling. Endocr Relat Cancer 7: 165-197

Raghow R, Postlethwaite AE, Keski-Oja J, Moses HL, Kang AH (1987) Transforming growth factor-beta increases steady state levels of type I procollagen and fibronectin messenger RNAs posttranscriptionally in cultured human dermal fibroblasts. J Clin Invest 79: 1285 - 1288

Roberts AB, Sporn MB (1988) Advances in Cancer Research pp 107-145, New York: Academic

Roberts AB, Sporn MB, Assoian RK, Smith JM, Roche NS, Wakefield LM, Heine UI, Liotta LA, Falanga V, Kehrl JH, Fauci AS (1986) Transforming growth factor type beta: rapid induction of fibrosis and angiogenesis in vivo and stimulation of collagen formation in vitro. Proc Natl Acad Sci USA 83: $4167-4171$

Samuels V, Barrett JM, Bockman S, Pantazis CG, Allen Jr MB (1989) Immunocytochemical study of transforming growth factor expression in benign and malignant gliomas. Am J Pathol 134: 894-902

Sappino AP, Schurch W, Gabbiani G (1990) Differentiation repertoire of fibroblastic cells: expression of cytoskeletal proteins as marker of phenotypic modulations. Lab Invest 63: 144-161

Shinozaki M, Kawara S, Hayashi N, Kakinuma T, Igarashi A, Takehara K (1997) Induction of subcutaneous tissue fibrosis in newborn mice by transforming growth factor beta-simultaneous application with basic fibroblast growth factor causes persistent fibrosis. Biochem Biophys Res Commun 240: 292-297

Stahle-Backdahl M, Maim J, Veress B, Benoni C, Bruce K, Egesten A (2000) Increased presence of eosinophilic granulocytes expressing transforming growth factor-betal in collagenous colitis. Scand J Gastroenterol 35: $742-746$

Tahara E (1990) Growth factors and oncogenes in human gastrointestinal carcinomas. J Cancer Res Clin Oncol 116: 121-131

Varga J, Rosenbloom J, Jimenez SA (1987) Transforming growth factor beta (TGF beta) causes a persistent increase in steady-state amounts of type I and type III collagen and fibronectin mRNAs in normal human dermal fibroblasts. Biochem J 247: $597-604$

Walker RA, Dearing SJ (1992) Transforming growth factor beta 1 in ducta carcinoma in situ and invasive carcinomas of the breast. Eur J Cancer 28: $641-644$

Warshaw AL, Fernandez-del Castillo C (1992) Pancreatic carcinoma. N Engl J Med 326: $455-465$

Wenger C, Ellenrieder V, Alber B, Lacher U, Menke A, Hameister H, Wilda M, Iwamura T, Beger HG, Adler G, Gress TM (1999) Expression and differential regulation of connective tissue growth factor in pancreatic cancer cells. Oncogene 18: 1073-1080

Wong DT, Elovic A, Matossian K, Nagura N, McBride J, Chou MY, Gordon JR, Rand TH, Galli SJ, Weller PF (1991) Eosinophils from patients with blood eosinophilia express transforming growth factor beta 1. Blood 78: 2702-2707

Yamanaka Y, Friess H, Buchler M, Beger HG, Uchida E, Onda M, Kobrin MS, Korc M (1993) Overexpression of acidic and basic fibroblast growth factors in human pancreatic cancer correlates with advanced tumour stage. Cancer Res 53: 5289-5296

Yoshida K, Yokozaki H, Niimoto M, Ito H, Ito M, Tahara E (1989) Expression of TGF-beta and procollagen type I and type III in human gastric carcinomas. Int J Cancer 44: 394-398 